\title{
Génie de la langue: The Genesis and Early Career of a Key Notion in Early Modern European Learning
}

\author{
TOON VAN HaL \\ University of Leuven, Belgium
}

Eighteenth-century scholars writing on languages were obsessed with the génie de la langue. This rather vague but very influential concept entailed a variegated cluster of characteristics ascribed to a particular language, and so highlighted the distinctiveness of an individual language in comparison to others. Because of this, it is especially prominent in texts of scholars defending their own vernacular language or downplaying other vernaculars. In the last decades, much attention has been given to the vicissitudes of this influential idea. Even so, the context from which it originally developed has remained underexposed. It is commonly traced back to the French author Amable de Bourzeys (1606-72), and this attribution has been accepted without further discussion. The present paper reveals the more remote history of the notion génie de la langue. Its main focus is on Early Christian Latin texts as well as Early Modern Neo-Latin texts of the late sixteenth and early seventeenth centuries. By demonstrating that the phrase was already used long before the seventeenth century, this paper aims to contribute both to the impressive Beleggeschichte of this influential notion and to the many transformations it underwent throughout history.

KEYWORDS génie de la langue, Early Christian authors, Theodor Bibliander, Amable de Bourzeys, translation

\section{Introduction}

In 1773, Hieronymus Andreas Mertens published a book entitled Das Genie der deutschen und französischen Sprache in den schweresten Nationalausdrücken. Its title was anything but original. In the same year, Pierre M. Cibot wrote a lettre de Pekin sur le génie de la langue chinoise. Similar titles appeared in large quantities in the years before and after 1773 . Modern scholars have often observed that eighteenthcentury intellectuals writing on language(s) were truly obsessed with the génie de la 
langue. This rather vague, but very influential concept entailed a variegated cluster of distinctive (mostly positive) features ascribed to a particular language. In this way, it highlighted the distinctiveness of an individual language in comparison to others. Yet the idea was assigned many divergent definitions, names, and implications, ${ }^{\mathrm{I}}$ even to the point that it became unclear to contemporaneous scholars what the term actually meant. ${ }^{2}$ In the last decades, scholars have paid much attention to the history, evolution, and vicissitudes of this influential concept, which may - eventually, and after many transformations - have given way to the so-called Sapir-Whorf thesis. ${ }^{3}$ By contrast, far less has been said about the context in which the collocation génie de la langue originally emerged, although the phrasing is commonly traced back to Amable de Bourzeys (I606-72). ${ }^{4}$ True, some scholars rightly pointed out that the idea of linguistic uniqueness predates the seventeenth century and the term génie de la langue. ${ }^{5}$ And, true again, narrowing down the investigation of a given concept (German 'Begriff', viz. a semantic value) to one of its designations (German 'Bezeichnung', viz. a linguistic value) is in most cases a methodological weakness to be avoided by scholars dealing with conceptual history (German 'Begriffsgeschichte'). Even so, if an influential and constitutive designation such as génie de la langue appears to be much older than has commonly been assumed, this prompts the questions how it was used

I Gerda Haßler's and Cordula Neis' Lexikon sprachtheoretischer Grundbegriffe contains an entry devoted to the 'besonderer Character einer Sprache', which offers a list of terms used to describe this idea, among which 'Lat. Genius linguae, Indoles linguae; dt. Genie der Sprache, Genius der Sprache; engl. genius of a language; frz. génie d'une langue, génie de la langue; ital. genio della lingua' (Haßler and Neis, 2009: s.v.). For the sake of convenience, I will stick to the French designation 'génie de la langue', in which the concept probably became best known. Most sources referred to in this paper are, however, composed in Latin.

2 The French author Antoine de Rivarol (I753-I8OI) observed in 1784 that '[o]n demande souvent ce que c'est que le génie d'une langue, et il est difficile de le dire' (quoted after Schlaps, 2004). For contemporary definitions, see Haßler and Neis (2009: s.v. 'besonderer Character einer Sprache'); see also Seidelmannus (I724: 79-8I).

3 See, e.g., the references in Schlaps (2004), Trabant (2006: I50-52), Haßler and Neis (2009). Recently, two books on the génie de la langue in France and Italy have appeared (Siouffi, 20Io and Gambarota, 20I I; see also Joseph, 20I2). The notion of génie de la langue still reverberates in twenty-first-century publications. This in itself suggests that the idea has not lost its relevance to contemporary thinking about language specificity and character (see Haßler, 20II: 66 for some illustrative examples). This is all the more remarkable since there is general consensus that the idea can of course not be used in serious linguistic analysis today.

4 See, e.g., Hüllen (200I) and Schlaps (2004). Haßler (20II: 65) is more cautious, stating that the phrase is at least as early as in 1635 present in France, hence not excluding its presence before that date. Christmann (I976: 68), who was the first to draw attention to Bourzey's contribution, had however openly stated that earlier attestations could probably be found. To my best knowledge, the hardly cited study of Schneiders (1995: 79-84) is the only work going beyond Christmann (1976) with respect to the roots of génie de la langue.

5 Stankiewicz (I98I), whose paper 'The "Genius" of Language in Sixteenth-Century Linguistics' has a much wider scope than its title suggests, argues that the uniqueness of individual languages was a central theme in sixteenth-century linguistics. While stating that 'the terms which seemed most appropriate to encompass the overt and covert properties of a language were "genius" and the expression je ne sai quoi' (Stankiewicz, I98I: I8I), the author regrettably does not offer a single example (see also the criticisms expressed by Schlaps, 2000: 306 and Gambarota, 20II: 236). He only refers to Horace, whom he claims to have used genius in connection with the Greek language. Yet I did not find anything of the like in Horace. See also infra, n. I5. 
and with what meanings, and how this relates to later applications of the term. Still, even in a case like this, it is important not to lose sight of the broader conceptual context that goes beyond particular designations. ${ }^{6}$

The present paper therefore purports to explore the more remote history of génie de la langue. It will demonstrate that the phrase was in use as early as in the first half of the sixteenth century. This is not to say that this paper is merely 'hunting' for the oldest attestation. I hope to provide a useful contribution both to the impressive Beleggeschichte of this influential notion and to the many transformations it underwent throughout history. A few words on methodology are in order here. Elsewhere, I already briefly observed that several Dutch humanists used the label genius with more or less obvious reference to the singularity and peculiarity of a language well before I635 (Van Hal, 2010: 427 [= published edition of a PhD-dissertation defended in 2008]). This already suggests that Bourzeys' génie de la langue was anything but a creatio ex nibilo. In taking this point further, this paper benefits from a recent technological evolution. The past five years have seen enormous progress in creating possibilities for automatically recognizing Early Modern scanned printed sources, which were virtually non-existent in 2008. On the one hand, Google succeeded in drastically improving the searchability of its historical E-books, which does not alter the fact that for a large number of books results remain poor. In addition, the European project IмРАст ('IMProving ACcess to Texts), which aimed at developing tools that could 'take away the barriers that stand in the way of the mass digitization of the European cultural heritage' < http://www.impact-project.eu>, presented its results in June 2OI2. The implementation of the project's outcomes will contribute considerably to the further disclosure of Early Modern books. Needless to say, these welcome technological developments can only enhance, but never replace the existing heuristic strategies available to scholars focusing on the Early Modern period, most notably creative and wide reading (cfr. Armitage, 20I2; Bamman and Smith, 20I2).

I thought it wise not to proceed in a chronological manner. A succinct discussion of the ideas about génie de la langue as expressed by Amable de Bourzeys is followed, therefore, by two paragraphs discussing some earlier antecedents (one century and one millennium back respectively). A subsequent, more lengthy part investigates the context and the circulation of the phrase throughout the sixteenth and seventeenth centuries.

\footnotetext{
6 Schlaps (2004: 367-68) deliberately limits her scope to "the terms "genius of language", "génie de la langue", "Geist/Genius/Genie der Sprache" and "Sprachgeist/Sprachgenius"'. She argues that her 'analysis is a genuinely linguistic one, unlike philosophical approaches in the history of ideas which tend to follow given abstract concepts throughout the history of texts or discourses without adequately discussing the lexemes, and their terminological status, involved. Here, concepts are understood as entities not phenomenologically, but linguistically constituted, therefore to be described linguistically'. Whereas Schlaps may be right in criticizing the terminological blindness in the work of some present-day conceptual historiographers, in my opinion she errs too much in the opposite direction.
} 


\section{Amable de Bourzeys (1606-72)}

Before delving deeper into the history of the génie de la langue, we must understand what the alleged prôtos heuretès meant by the phrase. On I2 February I635, Amable de Bourzeys, a French orientalist, held the third academic speech following the foundation of the French Academy. The text was printed only in the twentieth century under the title Discours sur le dessein de l'Académie et sur le différent génie des langues (Dryhurst, I97I). The title is deceitful, given the fact that the manuscript (preserved in the Bibliothèque [Nationale] de France, MS 31797) does not bear one. All the same, the heading can be traced back to an early book documenting the history of the French Academy (Pellisson-Fontanier, I653: I 59). In a much-quoted paper, Hans Helmut Christmann pointed out that Bourzeys' speech is the earliest text that deals with the génie de la langue (Christmann, I976). He thus corrected the erroneous idea that the origin of génie de la langue was rooted in the rational grammar of PortRoyal. Without any doubt, Bourzeys' speech is an important text in the history of the génie de la langue-concept, as the text, which is entirely devoted to this very notion, articulates a peculiar view on linguistic specificity. Writing in the atmosphere of the Querelle des Anciens et des Modernes, the author noted that '[c]haque langue a son air et son genie particulier' (Bourzeys, I635 = Dryhurst, I97I: 233). The idea behind this was that geography (climate), government, and customs impacted on the language the inhabitants of a particular region used. Accordingly, Bourzeys' definition of génie de la langue complies with Werner Hüllen's observation that the notion of génie de la langue throughout its history 'established a close link between a language and its speech community' (Hüllen, 200I: 242). But does this assessment hold for earlier attestations I was able to trace?

\section{One century back}

The Swiss scholar Theodor Bibliander (I505-64) offers the earliest Renaissance génie de la langue-attestation I discovered so far. In a I 542 book discussing Hebrew grammars, he expressed his surprise over the fact that the Hebrew language was not adequately described and explained, despite the considerable number of lexicographical and grammatical tools available. ${ }^{7}$ Surveying the reasons underlying this situation, he highlights among other things the contradictions he found in the manuscripts as well as scribal negligence. Importantly, however, he also adduced the genius of the Hebrew language as an explanation. It is a significant fact that for this he relied on

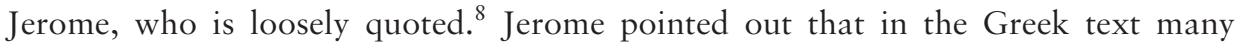
Hebrew words were simply transliterated 'because of translation problems and the

7 'Hebraica lingua nondum sit ad plenum explicata per Grammaticos tam Iudaeos quam Christianos' (Bibliander, I542: I2).

8 'Alicubi tamen Hieronymus voluntatem et eruditionem eorum [viz. the manuscripts' authors] tuetur, et causam interpretationis malae in librariorum incuriam, aut Hebraicae linguae genium transfert' (Bibliander, I542: I5). 
poverty of both the Greek and Latin language when compared to Hebrew'. ${ }^{9}$ Needless to say, Bibliander's observation offers an interesting passage, not only in view of its

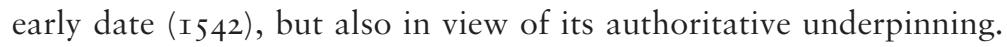

May we on this basis venture to conclude that the génie de la langue-phrase dates back to the Latin Church fathers? At first glance, other early génie de la langueattestations - many of which are concerned with the genius of the Hebrew language - confirm this suspicion. The French scholars Isaac Casaubon (I559-I6I4) and Louis Cappel (I $585^{-1658)}$, for instance, use the phrase more than once in connection with the then so-called Oriental (now so-called Semitic) languages. ${ }^{\text {IO }}$ The same holds true for the biblical scholars Bartholomaeus Mayer (I598-I63I), Ludovicus de Dieu (I590-I642), Ioannes Morinus (I59I-I659), and Constantin L'Empereur (I59I-I648), all of whom are contemporaries of Bourzeys. ${ }^{\text {II }}$ In addition, a connection between génie de la langue and the Church Fathers is suggested by both Arnaldus Pontacus and Johannes Jacobus Wissenbachius (I654: I47), who link their genius-remark

9 Jerome's text reads as follows: 'Multaque sunt nomina quae ita leguntur in Graeco, ut in Hebraico posita sunt, propter interpretandi difficultatem, et ad comparationem linguae Hebraeae, tam Graeci quam Latini sermonis pauperiem' (Commentarii in Isaiam, lib. II).

Io 'Sed non est alienum a genio dictionis Epiphanii, ut eam vocem pro liberos generare usurparit' (Casaubon, I6I4: 69); 'Totum discrimen in vocibus est, in re nullum est prorsus. Discrimen vocum facit diversus linguarum genius, \& in eadem lingua analogiae ratio dissimilis in diversis vocibus' (Casaubon, 1614: 265); 'Quod in terminatione nulla est diversitas, genio Syriacae linguae est tribuendum' (Casaubon, I6I4: 387); 'Syrus interpres in partes trahi non potest, neque Hebraeus: quia apud illos ex ipso genio illarum linguarum necessario committitur homonymia in his vocibus' (Casaubon, I6I4: 388); '[...] a se excogitatas Vocalium \& Accentuum figuras consonis addiderunt, quique cum eas aliis vocibus analogice, et ex linguae Hebraicae veluti genio ac natura addidissent, in illis certo consilio de industria, alienas, et vocibus ipsis vel maxime abhorrentas adscripsere' (Cappel, I624: 83); 'Argumenta autem potissimum sunt vel ab antiquitate, et Historia petita, vel sunt a rei Grammaticae ratione, sint potius a natura et veluti genio hujus linguae ducta, vel sunt denique (ut sic ea appellem) Theologica, quia iis Theologi potissimum utuntur' (Cappel, I624: I87; see also pp. I22; I67). See also De Bolleville (I621: 94): 'Pour expliquer les frequentes répetitions qui se trouvent dans les Livres de Moïse on a apporté dans l'Histoire Critique plusieurs raisons qui peuvent avoir causé ces sortes de redites dans un Historien. On a eu recours au genie de la Langue Ebraïque qui aime ces sortes de répetitions, comme il est aise de le prouver par les autres Livres de la Bible', Cameron (I642: 430) and Bangius (I634: lxiv).

II 'Adde, non aliunde melius phraseos Hebraicae energiam et proprietatem quam ex lingua peti Chaldaica, ut quae ex illa nata matris suae genium et indolem optime refert' (De Dieu, I628: ad lectorem); 'amaritiem praeceptionum Grammatices degustavit, hoc est, linguarum proprietatem et genium expendit, ex Ebraica veritate ac linguae sanctae indole divinissima vetus instrumentum, novum autem ex Hellenistica, quae ejus ex matre Graeca soboles, exponit' (Mayerus, I629: unnumbered); 'Verum quis non videt, hanc etymologiam esse confictam, et nil nisi insipidam quandam allusionem: quin et linguae Ebraeae genius hoc non admittit' (Mayerus, I629: unnumbered); 'ipsa phrasis et linguae Hebraeae genius indicant' (De Dieu, I63I: 356); 'ut propter ipsorum annotationem contra rationem Grammaticam \& linguae genium credam ibi affixum esse' (De Dieu, I63I: 493); 'iuxta linguae genium' (Morinus, I63I: 32I); 'Ab Hebraeo enim propius abest, magisque phrasim et genium Hebraicae linguae sapit Samaritica versio quae nobis est prae manibus' (Morinus, I63I: 37I); 'nobis tamen Orientalium linguarum genium non assequutis, neque in Graecis ita versatis, ut quod semel atque iterum in hoc vel illo authore Graeco occurrit, perspectum habeamus; nihil utilius, ne dicam necessarium, quam linguam Ebraeam Talmudicam et vicinas didicisse' (L'Empereur, I637: sig. *\%2v). 
directly to Jerome and Augustine respectively. ${ }^{\mathrm{I} 2}$ At first sight, this might seem to corroborate the idea that the humanists relied on the Church Fathers for their idea of the linguistic specificity of the Hebrew language. But can it be that the humanist scholars freely quoted the Church Fathers in support of their own views and so in fact put words in the mouth of their authority? In order to understand this more fully, we must turn to the use of the phrase 'génie de la langue' in late Antiquity before returning to the sixteenth and seventeenth centuries.

\section{One millennium back}

When we turn to the passage from Augustine, which Wissenbachius linked with his remark 'Suus cuique linguae est genius' ('every language has its own genius'; see note I2), it immediately occurs that Augustine did not use the word genius at all. The passage from which Wissenbachius quotes runs as follows:

the way of speaking/locution of the Holy Scriptures must be received in compliance with the specificities of every individual language for every language has its own proper sorts of locutiones which, once transferred into another language, seem absurd. ${ }^{\mathrm{I} 3}$

Although the first part of the passage is omitted by Wissenbachius, it entails a term (proprietas) that is used not only by Augustine, but frequently by other Early Christian authors as well. In combination with lingua, the term proprietas almost always refers to the concept of 'the particular character of a language'. Space limitations do not allow me to offer a comprehensive list of the usage here. Yet it is helpful to offer a few illustrative examples, most of which will prove to be useful to the line of argument as developed below. In his Commentarii in prophetas minores, for example, Jerome (lib. 3, cap. Io) writes: 'cogor contra uoluntatem meam saepius de hebraeae linguae proprietatibus disputare' ['I am forced against my will to deal quite often with the characteristics of the Hebrew language']. Augustine, in his turn, observes in his 5Ist Sermon: 'sed mulieres omnes feminas illi appellauerunt, proprietate linguae hebraeae' ['but they have styled all women "wives" ["spouses"], following the characteristics of the Hebrew language']. More examples of the kind can be adduced. ${ }^{\mathrm{I} 4}$

\footnotetext{
I2 'At melius multo est ex fontibus ipsis haurire, quam rivulos consectando, dum quis eorum purior sit non satis intelligitur, cuiusque interpretis sequi errorem, quod gravissimis viris accidisse auctor est D. Hieronymus. Deinde nescio quo genio, cuiusque linguae sua est proprietas et loquendi ratio, quae in aliam reddi nullo modo potest, quaque ignorata saepe in transversum discedendum sit ab authoris mente atque sententia. Verum haec obiter' (Pontacus, I566: unnumbered praefatio); 'Suus cuique linguae est genius, de quo Augustinus libro de vera relig. c. 50. Habet, inquit, omnis lingua sua quaedam propria genera locutionem, quae cum in aliam linguam transferuntur, videntur absurda' (Wissenbachius, I654: I47).

I3 'Ipsa locutio diuinarum scripturarum secundum cuius linguae proprietates accipienda sit - habet enim omnis lingua sua quaedam propria genera locutionum, quae cum in aliam linguam transferuntur, uidentur absurda' (Augustinus Hipponensis, De uera religione, cap. 50; all references to Early Christian Latin texts are after Brepols' digital Library of Latin Texts <www.brepolis.net>.)

${ }^{{ }^{4}}$ See, e.g., Marti (I974: II3-20) and Bartelink (I980: 52-53), who points out that Jerome's and Augustine's

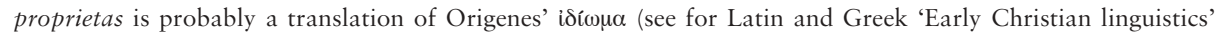
Denecker et al., 2012 and Van Rooy, 2013 respectively).
} 
Does this imply that the génie de la langue-collocation does not occur before the Early Modern Period? Magnus Felix Ennodius, born just before the official collapse of the Western Roman Empire (473-74 AD), left us c. 500 writings, which he composed in a notoriously difficult and affected style before he was appointed bishop of Pavia in 5 3 . In one of his letters (I,6, in which he praises God), he states, 'Linguarum genio terris merita tribuuntur et qualiter quis loqui potuerit, taliter rem de qua fuerit locutus, adtollit'. In an attempt to render Ennodius's opaque Latin style into English, one may translate his words as follows: 'by grace of the languages [linguarum genio] the merits are assigned to the countries and just as someone could talk, in such a manner he extols the thing on which he has talked'. So, do we have an example from the early sixth century? Apparently not. Throughout Ennodius' work, 'genius' can often be rendered with 'gift' (see, e.g., Kennell, 2000: II4). In any event, it seems that his 'incidental' collocation of genius and linguae stands isolated from the usage of proprietas linguae as found in other Early Christian Latin authors. On top of this, given the fact that the editio princeps of Ennodius' work was published in I569 (see Kennell, 2000: 23I), Bibliander cannot be indebted to this particular author for his use of génie de la langue.

\section{The early career of génie de la langue in the sixteenth and seventeenth centuries}

So far I have attempted to demonstrate that the génie de la langue-phrase was used well before the seventeenth century. In addition, I have investigated to what extent the phrase might be rooted in Early Christian Latin learning. I will now investigate how the phrase began its spectacular career throughout history by focusing on some important early attestations of the concept outside the context of Hebrew studies. In addition, I will further unveil the Early Modern authors' indebtedness to Early Christian Latin authors. Despite the absence of literal reminiscences of génie de la langue in the sources of the latter, I will attempt to prove that proprietas and genius can be considered synonyms.

A study of Early Modern génie de la langue-attestations outside the context of Hebrew studies soon reveals that the phrase there, too, was almost always applied with reference to translation practices. Hieronymus Wolfius (I5I6-80) - who translated Isocrates' Attic orations in the second quarter of the sixteenth century - complains about the difficulties to render in a satisfactory way the Greek 'sweetness', rooted in (its) 'some or other peculiar genius' (nescio quis peculiaris genius), into Latin. ${ }^{\mathrm{I}}$

\footnotetext{
${ }^{15}$ Wolfius (I548: II7): 'Ut enim non dicam, fieri minime posse, ut nescio quis peculiaris Graecae linguae genius, in quo maxima pars suavitatis et oblectationis plurimum inest, in alium sermonem transfundatur: quam multa depravari, quam multa obscurari, denique vel assuta, vel recisa temere a nonnullis [...] deprehendi?'. As to nescio quis, compare supra, n. I2 and Joachim du Bellay's famous phrase 'je ne scay quoy', expressing the veiled characteristics of a particular language: 'd'autant que chacune Langue a je ne scay quoy propre seulement à elle, dont si vous efforcez exprimer le naif en une autre langue, observant la loy de traduyre, qui est n'espacier point hors des limites de l'aucteur, vostre diction sera contrainte, froide et de mauvaise grace' (Bellay, Deffence et illustration de la langue francoyse, I 548, here quoted after Ford, 20I3: 24). As observed by Schneiders (I995: 8I-82), Du Bellay elsewhere makes use of the term génie (however not directly linked with 'langue').
} 
Martin Luther's alleged perfect command of the German language in his Bible translation was put into perspective in a I626 doctoral dissertation defended at a Bavarian Catholic theological faculty: 'so only Luther would have known the genius of the German language, and all others would not? O, most idle arrogance!'. ${ }^{16}$ In the first set of selected letters written by Justus Lipsius, one reads: 'Est suus videlicet cuique linguae Genius, quem non avellas, nec temere migrare iusseris in corpus alienum' ['every language has its own characteristics which cannot be torn away from it and simply transferred to another body'] (Lipsius, I 586: I85). The letter was destined for Balthasar Moretus (I574-I64I), who was translating Lipsius' philosophical masterwork De constantia into Dutch (see De Landtsheer, 2006: 45-47, and Meeus, 2006). The then Leiden professor, discussing a first sample of Moretus' work, points out that it is impossible to maintain the Latin brevitas ('conciseness', one of the characteristics pertaining to its genius) in the Dutch translation. ${ }^{17}$

Lipsius very likely gave a serious boost to the wide spread of the phrase génie de la langue. His letters enjoyed a wide circulation and an enormous popularity, as has been shown in many a study. ${ }^{18}$ It is therefore not surprising to find that some Early Modern sources literally echo Lipsius' observation. So, for instance, the Marburg professor Catharinus Dulcis (I540-I626) noted down the following words in his Schola Italica, a widespread introduction to Italian of the seventeenth century:

and one should try to present everything in a faithful, appropriate and proper way, while at the same time preserving both languages' property [proprietas]. Every language has its own characteristics [genius]. And the Italians have certain pecularities, which lose all charm if one tries to literally translate the Latin. ${ }^{19}$

Whereas in this case we cannot be sure that Lipsius provided the (prime) source for Dulcis, Henry Peacham (I578-c. I644) explicitly cited Lipsius in his well-known guidebook The Compleat Gentleman (1622):

But there being, as Lipsius saith, Suus cuique lingua genius: Let me aduise you of this by the way, that no Translation whatsoeuer will affect you, like the Authors owne and proper language.

I6 'Solus Lutherus verum genium Linguae Germanicae cognoverit, omnes alii ignorarint, o vanissimam superbiam' (Vischerus and Forerus, I626: $33-34$ ).

${ }^{17}$ It is interesting to note that in a later publication Lipsius connects brevitas once again with genius, although the former is not conceived of as a characteristic of a language but of an author (viz. Seneca): 'Verba, selecta, propria, significantia: imo quae plus aliquid semper dicunt, quam dicunt. Qui proprius quidam eius Genius

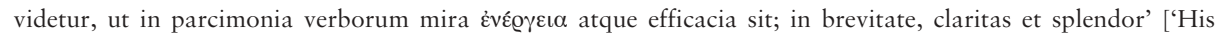
words are choice, suitable and significant; they always mean something more than they actually say. And this seems a special genius of his, that in an economy of words he has a wonderful force and efficacy; in brevity he has clearness and brilliance'] (Lipsius, 1604: 57; translation Anderton, 1977: 29). Due to reasons of space, this connection will not be further explored here.

${ }^{18}$ For a case study relevant to the history of linguistics, see Deneire and Van Hal (2006).

I9 ' $[\ldots]$ et conandum ut omnia fideliter, apte, proprie exponantur, servata utriusque sermonis proprietate. Est enim suus cuique linguae Genius. Et sunt Italis quaedam peculiaria, quae si Latine coneris ad verbum reddere, omnem gratiam amittant' (Dulcis, I605: II). 
Like his Leuven predecessor, Erycius Puteanus (I574-I646) boasted on his feeling for the style of Latin. He started the first chapter of a 1623 book devoted to Amoenitas with the following words: 'everyone knows that the Roman language has a delicate genius, which is all too often violated by the promiscuous mass of speakers and writers' ${ }^{20}$

At this point we must reconsider the link between Early Christian Latin proprietas and Early Modern genius. Whereas it is difficult to trace a decisive link between Ennodius's génie de la langue and the sixteenth-century reappearances of the same collocation, one can easily show that Early Modern authors continued to use the word proprietas in the same sense as the Church fathers did. ${ }^{2 \mathrm{I}}$ In addition, I think one can convincingly demonstrate that sixteenth-century humanists started to use genius and proprietas as interchangeable terms. As early as in I5I9, one of the participants in Jacobus Latomus' (c. I475-I544) dialogue 'on the three languages' stated:

'Principio unaquaeque lingua suum habet idioma, quod transfundi non potest. [...] Quod cuique linguae sua proprietas inest, quae in aliam transfundi nequit' (litt. 'first each language has its idiom, which cannot be translated. [...] because in each language is its own proprietas, which cannot be translated into another one'). (Latomus, I5I9: II, I2) 22

This recalls both Augustine's statement (see note I3) and Lipsius' observation. A few years later, an anonymous author comments on a passage of Augustine as follows:

Sua cuique linguae proprietas est. Et idiotismus [...]. locutio divinarum scripturarum secundum cuiusque linguae proprietatem accipienda est. Habet enim omnis lingua quaedam propria locutionum genera: quae quum in aliam transferuntur, videntur absurda. (Anon., I556: IIO)

20 'Delicatum Romani sermonis genium esse, et in promiscua loquentium scribentiumque turba saepius violari, nemo unus nescit'. On page 86 above, I discussed a passage in Wissenbachius (I654: I47). He makes use of the same collocation as Lipsius. Benedictus (I619: unnumbered Praefatio): 'Nolim enim tam bene de me sentire, ut contendam me tibi versionem istiusmodi exhibere, quae omnis censurae expers esse possit: quandoquidem ardua res est eadem elegantia, eademque festivitate authorem hunc de Graeca phrasi in Latinam transferre: ita proprius est unicuique linguae genius et inexplicabilis venustas'. See furthermore: 'Innumera, mihi credite, sunt quae adoptari recusant: quae si in aliam transferre et transformare linguam conamur, vis omnis et venus simul perit: non aliter quam herbae quaedam et arbores, si loco moventur et in aliud migrant solum et caelum, prorsus degenerant, et aut nullos plane fructus, aut pro dulcibus acerbos et amaros gignunt. Sua cuique linguae gratia, suus inest decor et nativa quaedam forma, quam nollo mentiri fuco, nullis exprimere pigmentis vel egregius artifex possit' (Rubenius, I6I5: 220). Finally, one could quote 'ita unicuique linguae inest suus Genius et proprius lepos, qui si in externum sermonem traducatur, non modo plerumque nullam gratiam, sed saepe etiam risum meretur' (Lauxmin, I658: I43-44).

${ }^{21}$ Also Schneiders (I995: 36) suggested that Early Christian proprietas and Early Modern genius may have had similar meanings. He however does not further substantiate his fine intuition.

${ }^{22}$ Not all contemporary humanists agreed over the principle that a language's proprietas was basically untranslatable. See, e.g., Bartolomeo Ricci's (I490-I569) opinion: 'Nam, quod ad difficillimam translationem, atque propriam venustatem attinet, nihil est tam cuique linguae proprium, tamque in eam natum, atque ingenitum, quod in quamque velis, transferri, atque explicari non possit' (Ricci, I560: 88r). 
The phrase is also voiced at least twice by Johannes Drusius (1550-16I6). ${ }^{23}$ Needless to say, the similarities between Lipsius' 'suus videlicet cuique linguae Genius' and 'sua cuique linguae proprietas est' are unmistakable. In my view, the very fact that genius and proprietas are used by sixteenth-century scholars in exactly the same construction strongly, if not conclusively, suggests that both terms are (almost) synonymous or at least interchangeable. This is even further substantiated in a dictionary composed by the famous pedagogue J. A. Comenius (I592-I670), who defined the headword proprietas linguae as genius linguae. ${ }^{24}$

To the best of my knowledge, present-day researchers who are eager to learn the exact meaning of a rather vague word tend to rely on contemporary dictionaries exclusively. ${ }^{25}$ Yet, besides focusing on dictionaries, it is equally or even more important to explore the textual contexts in which the respective word is mentioned and try to find some parallels so as to enhance one's understanding of the usage of the word. We already saw that genius is often used in exactly those collocations in which also proprietas is employed. There is another relevant collocation in which genius frequently turns up. The well-known biblical scholar Samuel Bochart (I599-I667) always seems to use genius linguae $X$ in connection with the Latin verb [non] ferre ('[not] to allow, to bear, to tolerate'). So, for instance, he states: 'And the genius of the Greek language does not allow that nouns coalesce with nouns in another way'. Other work of contemporary scholars exhibit similar formulations. ${ }^{26}$ These examples can be paralleled with comparable collocations (attested at least from I5I4 onwards) that combine the verb [non] ferre (or pati, admittere) and usus linguae 'the use of the

23 ' [...] sua cuique linguae proprietas est' (Drusius, I603: 25); 'Cuique linguae sua proprietas, suus idiotismus' (Drusius, I6I7: 278). See also Becmanus (I629: 97-98): 'Nempe cuique linguae propria ac peculiaris quasi congenita est convenientia ac series; quam si mutes, hoc est, si postponas, quae solet praeponere, et contra, iam decus elegantiae tabescat'.

${ }^{24}$ Comenius (1657: 587), see also the quote from Dulcis on p. 89. Another word that could be regarded as a synonym for genius is indoles ('an inborn or native quality, natural quality, nature'), see Comenius (I644: 284-85): 'Spectandum quidem esse, ut Translatio, quoad ejus fieri per Linguae genium potest, sit ad Verba quam maxime adstricta. Interim, nec consultum fore, ita usquam stricte id assectari, ut propterea, seu Nativa Linguae Latinae elegantia [...] seu Germanae propria indoles, negligatur'. See also Bangius (I634: lxiv), the book titles of, e.g., Schudt (I7I3) and Breitinger (I737: '[...] linguae sanctae genium, indolem ac proprietatem [...]') and supra, n. I, II, 25, 28, 29. See also the rhetorical question 'Non est suum cuique linguae idioma?' in Cueva ( 1550 : I5), suggesting that idioma also interlocks with genius.

${ }^{25}$ By way of example, I here offer two examples of the definition of Genius as found in Early Modern dictionar-

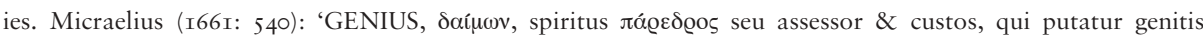
statim adesse, sive bonus sit et $\dot{\alpha} \lambda \varepsilon \xi \dot{x} \alpha \alpha$ genius sumitur pro natura et indole'; Kirschius (I774: I280): 'Genius, ii, m. [I)] Geburtsgeist, welcher, nach der Meynung der Heyden, den Menschen von der Geburt an zugesellet wird. Apul. 2) das Glück, der Zustand. Plaut. 3) ein Schutzgott. Genius loci. Seru. 4) die menschliche vom Leibe abgeschiedene Seele. Apul. 5) die natürliche Art, angebohrne Neigung'.

${ }^{26}$ See, e.g., Bochart[us] (I646: 746): 'Quia non fert linguae Hebraeae genius'; Hottinger (I644: 48): 'Sed hoc vix videtur ferre genius linguae Aegyptiacae'; Hottinger (I659: 24): 'Hae tamen Etymologiae omnes incertae sunt, et allusivae potius, quam propriae, tum a genio lingua Hebraeae, quae voces appellativas composita aegre admittit, alienae, tum etiam praeceptis Grammaticis male accomodotae'; Jacobus Gretserius (I6II: I38): ‘Nam in his transitionibus ex Graecia in Latium, aut vice versa, non observatur semper idem sonus, sed plerunque mutatio aliqua intervenit, prout fert genius linguae et loquentium voluntas'; Maresius (I673: I25): [...]'quod alias non fert genius linguae Arabicae [...]'; Vorstius (I658: I47): 'ut genius linguae Latinae requirit'. 
language', consuetudo linguae 'the habit of the language', or just lingua. ${ }^{27}$ All this suggests that the phrase génie de la langue was in its origin basically used in the context of translation business.

Nevertheless, we can see that in some texts génie de la langue is also employed as a yardstick for comparing languages. That is to say that in these cases the phrase is used not to indicate discrete or subtle differences between two languages that impede easy translation, but instead to contrast two (or more) languages in their entirety. When the genius of a given language does not deviate too much from the genius of another language, both languages may be related. Rather than stressing the idiomatic peculiarities of a given language, the term genius here refers to the overall character and structure of a language. Johannes Isacius Pontanus (I57I-I639), a firm champion of the equation between Germanic on the one hand and Bretonic and Welsh on the other, states that 'the old Bretonic and British language are very similar to Germanic, not only with regard to genius and indoles, but also regarding words and phrasis'. ${ }^{28}$ It remains vague what exactly Pontanus referred to when he used genius and indoles ('spirit' and 'character'), as he does not elaborate on these terms, let alone define them. Remarkably, the Dordrecht scholar Abraham Mylius (I563-I637) applied the term in an equally (vague) way and used the same combination with indoles. He did so in response to the question why it was more probable that the Greeks borrowed words from the Dutch than vice versa. Mylius stated that (I) Celtic [...] is older than Greek, and that (2) the shared words exhibit the 'Celtic' genius and indoles rather than the Greek one. He demonstrated the alleged 'Celtic' origin of the words shared by 'Celtic' and Latin in similar fashion. ${ }^{29}$ A comparable use of the term turns up in a letter which the aforementioned Leiden scholar Ludovicus de Dieu addressed to James Ussher (I58I-I656), Archbishop of Armagh. In it, he comments upon the linguistic theories developed by Johannes Elichmann (I60I/O2-39), who

started a gradual comparison of the Germanic language in all its dialects, and also of Latin and Greek, with the Persian language. Persian shares with those languages, and particularly with Germanic and our Dutch language, an affinity which, as I have been shown, is very great. Hence, he also wants to investigate the genius of Irish; this language might turn out to be closer to Persian than the others. ${ }^{30}$

${ }^{27}$ See, e.g., Reuchlin (I5I4: unnumbered): 'Postea ut multiloquentis fert linguae consuetudo'; Lorini (I6I2: I7I): 'quam non ita fert usus Latini nominis lingua'; Chamier (I626: 737): 'quod non fert linguae sacrae usus'; Calvin (I67I: 58): 'ut fert linguae usus'; Valla (I544: 64): 'quod Latinitas non patitur'; Rivetus (I625: I28): ‘lingua non fert'.

${ }^{28}$ Pontanus (I606: I66): 'Accedit quod vetus illa Britonum Aremorica lingua vetusque Britannica [...] non modo genium atque indolem, sed verba subinde et phrasin quoque Germanicam, ut maxime, redoleant'.

${ }^{29}$ Mylius (I6I2: 8I): 'Primo, quod Celtica lingua sit Graeca antiquior. Secundo, quod vocabula communia magis referunt Celticum quam Graecum genium et indolem'; Mylius (I6I2: IOO): '[...] credibilius est plurimas dictionum harum similium habere Latinos ex Celtica, quam Belgas ex lingua Latina, quia inquam genium magis spirant Belgicum, quam Latinum'. Interestingly, Mylius (I6I2: 72) equates indoles in its turn with ingenium and character ('[...] simile ingenium, similem characterem, similem indolem').

${ }^{30}$ Elrington (I864: II-I4): 'coeperit paulatim linguam Germanicam per omnes eius dialectos, Latinam item et Graecam cum Persica conferre, quippe quae cum istis, praesertim cum Germanica nostraque Belgica ingentem, quod experti loquimur, affinitatem habeat, Irlandicae quoque genium explorare cupit, si haec fortassis propius ceteris ad eam accedat'. 
Finally, the Leiden merchant and historian Johannes de Laet (I 58 I-I649) also applied the term in a similar context. In his famous response to Hugo Grotius's (I $583-\mathrm{I} 645$ ) notorious publication regarding the origin of the Indians, De Laet rejected the genealogical connection between the Indians and the Nordic people that Grotius advocated, and pointed out - rather convincingly — that a small set of similar words does not suffice to prove a common origin: 'one should pay attention to the language's or dialect's proper genius, its manner of pronunciation, its way of constructing, and most importantly the words referring to the indigenous and most common things of that people'. ${ }^{3}$ Needless to say, scholars could also argue that two languages were unrelated, if their geniuses differed considerably. ${ }^{32}$

\section{Conclusions}

This paper has shown that the génie de la langue-phrase was recorded for the first time at least almost one century before Amable de Bourzeys' I635 speech, not later than the first half of the sixteenth century. Significantly, it was coined to indicate the subtle properties of a certain language giving way to serious translation problems. It appears that the collocation was synonymous with the much older phrase proprietas linguae, which dates back to the Church Fathers. Also the notion of génie de la langue is therefore indebted to the classical tradition (see Grafton et al., 20I0). It is important to realize that, as a synonym for proprietas or indoles, the term genius did not entail any special 'spiritual' connotations in the sixteenth and early seventeenth centuries. It is in particular noteworthy that in none of the instances surveyed in this paper the character of a language is linked with the character of a nation, a link that is pivotal to modern conceptualizations of génie de la langue. Against the background of this, Bourzeys (who as a specialist in Greek and Oriental languages probably borrowed the phrase from one of the sources I presented in this paper) so far stands out as the first to interpret genius in a 'national' manner. This is, on the other hand, not to say that the arguments he developed were entirely new (cfr. also Schneiders, I995: 83). Already in antiquity, connecting a nation's lingua to its mores was a frequent ethnographic topos (see Van Hal, 20I3). This procedure had been adopted by many humanists, who regularly discussed a nation's lingua and mores together. And the idea that climate and government could impact on a people's language was most famously formulated by Jean Bodin (I530-96). In sum, Bourzeys did not stand at the beginning of the génie de la langue-story. He rather infused an older word with new meaning which would gain particular significance in the age of emergent nationalism looking for national distinction and supremacy.

\footnotetext{
${ }^{31}$ De Laet (I643: 30-3I): 'Non satis est paucula vocabula sive integra, sive paululum, secundum varias dialectos, detorta reperiri, sed oportet ipsum linguae aut dialecti genium, pronuntiandi rationem, constructionis modum, et inprimis nomina earum rerum quae domesticae et maxime communes illi genti sunt, attendere. Nam alias non difficile est in omnibus linguis reperire vocabula, convenientia aliquo modo cum aliis linguis'.

32 See e.g. a note made by Claude de Saumaise (I588-I653) in a Sulpicius Severus commentary (Hornius, I654: 6I): 'Caeterum ex colloquio Iosephi cum fratribus patet, plane aliam Aegyptiorum atque Hebraeorum linguam fuisse. Idque etiam ex Glossariis Copticis, et totius linguae genio patet'.
} 
It goes without saying that this conclusion is only preliminary. It is very well possible, for instance, that new sources will uncover an even older relationship between the notions of genius linguae and genius populi than in Bourzeys' text, or an attestation of génie de la langue that predates Bibliander's I542 book. A more thorough study of fifteenth- and sixteenth-century sources may additionally shed new light on subtle differences between the different terms used by authors to style génie de la langue. Apart from proprietas, indoles, character, ingenium, one could investigate to what extent authors draw on words such as natura and spiritus. A more detailed investigation into the wider context of the collocation is also likely to yield enlightening results. It is reasonable, for instance, to assume that in grammatical contexts the use of genius linguae or one of its alternatives has other implications than in philosophical works. And what is the connection between génie de la langue and such ubiquitous, yet rather vague concepts as usus, consuetudo, idioma, ratio, and analogia? ${ }^{33}$ It is my hope that this contribution has at least demonstrated that such questions cannot be answered without taking into account the classical tradition and the extensive range of Early Modern Neo-Latin sources.

\section{Acknowledgements}

I am very much indebted to the stimulating feedback and further references given by Tim Denecker, Gerda Haßler, Lambert Isebaert, Han Lamers, Pierre Swiggers, and two anonymous referees. I am very grateful to the Henry Sweet Society for awarding an earlier version of this paper the Vivien Law Prize 20I2. The considerable amount of primary sources compelled me to show more restraint in citing secondary literature.

\section{Bibliography}

\section{Primary sources}

Anon. I556. Apostoli describentis episcoporum, presbyterorum, et diaconorum mores oqueíwoıs ex viginti quinque Gratiani distinctionibus excerpta [...]. Parisiis: Apud Andream Wechelum.

Bangius, Thomas. I634. Exercitatio glottologica [...]. Hafniae [Kopenhagen]: Typis Salomonis Sartorii.

Becmanus, Christianus. 1629. Manuductio ad Latinam linguam, nec non de originibus Latinae linguae [...]. Hanoviae [Hannover]: Sumptibus Clementis Schleichii, et Viduae Danielis Aubrii.

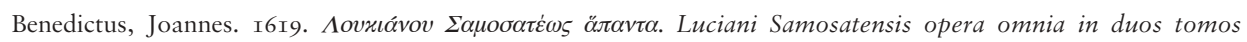
divisa. Salmurii [Saumur]: ex typis Petri Piededii.

Bibliander, Theodor. I542. De optimo genere grammaticorum Hebraicorum commentarius. Basileae [Basel]: Curio.

Bochartus, Samuel. 1646. Geographiae sacrae pars prior Phaleg, seu de dispersione gentium et terrarum divisione facta [.... Cadomi [Caen]: Typis Petri Cardonelli.

De Bolleville, Le Prieur. I62I. Réponse au livre intitulé Sentimens de quelques Théologiens de Hollande sur l'Histoire Critique du Vieux Testament. Amsterdam: Chez Pierre de Coup.

33 See Haßler and Neis (2009) for a thorough discussion of these concepts. I am indebted to Lambert Isebaert and one of the anonymous referees for most of these suggestions for further study. 
Breitingerus, Jo[hann] Jac[ob]. I737. Brevis de idiotismis sermonis Hebraei commentarius; qui linguae sanctae genium, indolem ac proprietatem clare exponit [...]. Tiguri [Zürich]: Litteris Heideggeri \& Socc.

Calvin, Jean. I67I. Opera omnia, in novem tomos digesta. Amstelodami [Amsterdam]: apud viduam Joannis Jacobi Schipperi.

Cameron, Johannes. I642. $\tau \grave{\alpha} \sigma \omega \zeta \delta ́ \mu \varepsilon v \alpha$ [... . Francofurti: In Officina Clementis Schleichij Haeredum [...].

Cappel, Louis. I624. [Sôd han-nîqqûd han-nigleh] Hoc est arcanum punctationis revelatum. Sive de punctorum vocalium \& accentuum apud Hebraeos vera \& germana antiquitate diatribe, ed. by Thomas Erpenius. Lugduni Batavorum [Leiden]: Apud Iohannem Maire.

Casaubon, Isaac. I6I4. De rebus sacris et ecclesiasticis exercitationes XVI [. . .]. Londoni: ex Officina Nortoniana, apud Ioan. Billium.

Chamier, Daniel. I626. Panstratiae Catholicae tomus secundus. Genevae: Typis Roverianis.

Comenius, Joannes Amos. I644. Pansophiae prodromus, et Conatuum Pansophicorum dilucidatio. Lugduni Batavorum [Leiden]: Ex Officina Davidis Lopez de Haro.

Comenius, Joannes Amos. I657. Lexicon atriale Latino-Latinum. Amstelodami [Amsterdam]: Apud Joannem Janssonium.

Cueva, Martinus. I550. De corrupto docendae grammaticae Latinae genere, et de ratione eiusdem breviter recteque tradendae libellus. Antverpiae [Antwerp]: Iohannes Gravius.

De Dieu, Ludovicus. I628. [.. .] Grammatica linguarum Orientalium Hebraeorum, Chaldaeorum et Syrorum inter se collatarum. Lugduni Batavorum [Leiden]: Ex officina Elseviriana.

De Dieu, Ludovicus. I63I. Animadversiones sive commentarius in quatuor Evangelia, in quo collatis, Syri inprimis, Arabis, Evangelii Hebraei, Vulgati, Erasmi \& Bezae versionibus, difficiliora quaeque loca illustrantur, \& variae lectiones conferuntur [...]. Lugduni Batavorum [Leiden]: Ex Officina Bonaventurae \& Abrahami Elzevir.

Drusius, Johannes. I603. Elohim sive de nomine Dei Elohim. Franekerae [Franeker]: Ex officina Aegidii Radaei.

Drusius, Johannes. I617. Ad loca difficiliora Pentateuchi, id est quinque librorum Mosis commentarius. [...] Opus posthumum. Franekerae Frisiorum [Franeker]: Excudebat Fredericus Heynsius.

Dulcis, Catharinus. 1605. Schola Italica in qua praecepta bene loquendi facili methodo proponuntur [...]. Francoforti: E Typographeo Wolfgangi Richteri.

L'Empereur, Constantinus. I637. [Baba ḳamma mi-masekhet Nezikin] De legibus Ebraeorum forensibus liber singularis. Lugd. Batavorum [Leiden]: Ex Officina Elzeviriorum.

Gretserius, Jacobus. I6II. Institutionum linguae Graecae liber tertius de Syllabarum Dimensione [...]. Editio Nona. Ingolstadii [Ingolstadt]: Ex Typographeo Adami Sartorii.

Hornius, Georgius. ed. I654. Sulpici Severi Presbyteri opera omnia. Editio secunda auctior et emendatior. Lugduni Batavorum [Leiden]: apud Franciscum Hackium.

Hottingerus, Johannes Henricus. 1644. Exercitationes anti-Morinianae [...]. Tiguri [Zürich]: Typis Joh. Jacobi Bodmeri.

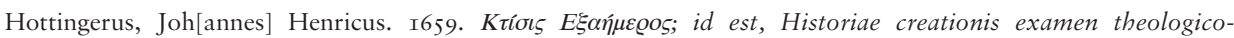
philologicum [...]. Heidelbergae: ex typographeio Samuelis Brouni.

Kirschius, Adamus Fridericus. I774. Abundantissimum cornucopiae linguae Latinae et Germanicae selectum. Editio novissima. Lipsiae [Leipzig]: sumtu Engelharti Beniaminis Suikerti.

De Laet, Johannes. I643. Notae ad dissertationem Hugonis Grotii de origine gentium Americanarum. Amstelodami [Amsterdam]: Elzevir.

Latomus, Jacobus. I519. De trium linguarum et studii theologici ratione dialogus. Apologia, rejiciens quorundam rumores natos ex dialogo D. Iacobi Latomi, ed. by Erasmus Roterodamus. Lovanii [Leuven]: Joannes Frobenius.

Lauxmin, Sigismund. I658. Praxis Oratoria [...]. Monachii [Munich]: Typis Lucae Straub.; Sumptibus Ioannis Wagneri.

Lipsius, Justus. I586. Epistolarum selectarum, centuria prima. Antverpiae [Antwerp]: Apud Christophorum Plantinum.

Lipsius, Justus. I604. Manuductio ad Stoicam Philosophiam. Antverpiae [Antwerp]: Ex officina Plantiniana, apud Joannem Moretum.

Lorini, Johannes. I622. In catholicas BB. Iacobi et Iudae apostolorum epistolas commentarii. Moguntiae [Mainz]: sumpt. Ioannis Crittii Viduae. 
Maresius, Samuel. I673. Systema Theologicum. Groningae [Groningen]: Apud Aemilium Spinneker.

Mayerus, Bartholomaeus. 1629. Philologiae Sacrae pars prima, continens prodromum Chaldaismi sacri, in quo ejusdem causa eruitur, ac sylloge vocabulorum Aegyptiacorum, Graecorum et Latinorum, quae in Veteris Instrumenti authentico codice, partim revera, partim opinione quorundam habentur, exhibetur. Lipsiae [Leipzig]: Sumtibus Gothofredi Grosii Bibliop.; Excudebat Johann-Albertus Minzelius.

Micraelius, Joh[annes]. I66I. Lexicon philosophicum terminorum philosophis usitatorum [....]. Editio Secunda. Stetini [Stettin]: impensis Jeremiae Mamphrasius, Typis Michaelis Höffneri.

Morinus, Ioannes. I63I. Exercitationes ecclesiasticae in utrumque Samaritanorum Pentateuchum [...]. Parisiis: Excudebat Antonius Vitray.

Mylius, Abraham. I6I2. Lingua Belgica sive de linguae illius communitate tum cum plerisque aliis, tum praesertim cum Latina, Graeca, Persica, deque communitatis illius causis, tum de linguae illius origine et latissima per nationes quamplurimas diffusione, ut et de ejus praestantia. Lugduni Batavorum [Leiden]: Ulricus Cornelii et G. Abrahami.

Peacham, Henry. I622. The compleat gentleman [...]. [London]: [John Legat].

Pellisson-Fontanier, Paul. I653. Relation contenant l'histoire de l'Académie françoise. Paris: Pierre le Petit.

Pontacus, Ar[naldus]. I566. Vaticinationes Abdiae, Ionae et Sophoniae prophetarum, Caldaea expositione, quatenus variat ab Hebraeo [...]. Parisiis: Apud Martinum Iuvenem.

Pontanus, Johannes Isacius. I606. Itinerarium Galliae Narbonensis, cum duplici appendice id est universae fere Galliae descriptione Philologica ac Politica. Cui accedit glossarium Prisco-Gallicum seu de lingua Gallorum veteri Dissertatio. Lugduni Batavorum [Leiden]: ex officina Thomae Basson.

Puteanus, Erycius. I623. Unus et omnis. Amoenitas bonae mentis: qua unius, o sic omnis, vis ac proprietas, partim sermonis, partim rerum varietate explicatur. [...]. Lovanii [Leuven]: Apud Ioan. Oliverium \& Coenestenium.

Reuchlin, Johannes. I5I4. Liber de verbo mirifico. s.n.: ex aedibus Thomae Anshelmi Badensis.

Ricci, Bartolomeo. I560. Epistolarum familiarum libri octo. Bononiae [Bologna]: s.e.

Rivetus, Guilielmus. I625. Libertatis ecclesiasticae defensio [...]. Genevae: Petrus Aubertus.

Rubenius, Philippus. I6r5. S. Asterii episcopi Amaseae Homiliae Grcè̀ \& Latinè nunc primùm editce Philippo Rubenio interprete [...]. Antverpiae [Antwerp]: Ex officina Plantiniana, apud viduam \& filios Ioannis Moreti.

Schudt, Joh. Jacobus. I713. Genius et indoles linguae sanctae sive commentarius grammaticus et criticus. Francofurti ad Moenum: Sumtimbus Frider. Knochii et filii.

Seidelmannus, Christianus Fridericus. 1724. Tractatus philosophico-philologicus de methodo recte tractandi linguas exoticas [...]. Wittenbergae: apud Vidvam Gerdesiam.

Valla, Lorenzo. I544. Elegantiarum latinae linguae libri sex [...]. Lugduni [Lyon]: Apud Seb. Gryphium.

Vischerus, Xistus and Forerus, Laurentius. 1626. Septem characteres reformatoris Germaniae Martini Lutheri [...]. Dilingae [Dillingen]: Apud Iacobum Sermodi.

Vorstius, Johannes. 1658. Philologia sacra, qua, quicquid Hebraismorum in toto Novo Test. reperitur, id pene omne recensetur, in certas classes digeritur, atque ipsarum ling. Orientalium collatione illustratur [. . .]. Lugduni Batavorum [Leiden]: Ex Officina Iohan. Zacharias Baron.

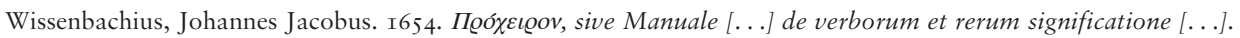
Franekerae [Franeker]: Impensis Gerhardi Schick.

Wolfius, Hieronymus. I548. Isocratis Orationes omnes [. . . e Graeco in Latinum conversae. Basileae [Basel]: per Ioannem Oporinum.

\section{Secondary sources}

Anderton, Basil. 1977. Sketches from a Library Window. New York: Books for Libraries Press.

Armitage, David. 20I2. What's the Big Idea? Intellectual History and the Longue Durée. History of European Ideas, 38: 493-507.

Bamman, David and Smith, David. 20I2. Extracting Two Thousand Years of Latin from a Million Book Library. Journal on Computing and Cultural Heritage, 5: I-I3.

Bartelink, G. J. M. I980. [Hieronymus'] Liber de optimo genere interpretandi (Epistula 57). Ein Kommentar. Lugduni Batavorum [Leiden]: Brill. 
Christmann, Hans Helmut. 1976. Bemerkungen zum Génie de la langue. In: Albert Barrera-Vidal, Ernstpeter Ruhe, and P. Schunck, eds. Lebendige Romania. Festschrift für Hans-Wilhelm Klein überreicht von seinen Freunden und Schülern. Göppingen: Kümmerle, pp. 65-79.

Denecker, Tim, Partoens, Gert, Swiggers, Pierre, and Van Hal, Toon. 20I2. Language Origins, Language Diversity, and Language Classification in Early Christian Latin Authors. Outline of a Research Project in progress (20I I-20I5). Historiographia Linguistica, 39: 429-39.

Deneire, Tom, and Van Hal, Toon. 2006. Lipsius tegen Becanus. Over het Nederlands als oertaal. Editie, vertaling en interpretatie van zijn brief aan Hendrik Schotti (I9 december I598). Amersfoort: Florivallis.

Dryhurst, James. ed. I97I. [Amable de Bourzeys'] Discours sur le dessein de l'Académie et sur le différent génie des langues. Zeitschrift für französische Sprache und Literatur, 8I: $225^{-42}$.

Elrington, Charles Richard. ed. I864. The Whole Works of the Most Rev. James Ussher. Dublin: Hodges, Smith, and Co.

Ford, Philip. 2013. The Judgment of Palaemon: The Contest between Neo-Latin and Vernacular Poetry in Renaissance France. Leiden and Boston: Brill.

Gambarota, Paola. 20II. Irresistible Signs: The Genius of Language and Italian National Identity. Toronto: University of Toronto Press.

Grafton, Anthony T., Most, Glenn W., and Settis, Salvatore, eds. 2010. The Classical Tradition. Cambridge, Mass.: Belknap Press of Harvard University Press.

Van Hal, Toon. 2008. Moedertalen en taalmoeders. Methodologie, epistemologie en ideologie van het taalvergelijkend onderzoek in de renaissance, met bijzondere aandacht voor de bijdrage van de humanisten uit de Lage Landen. Unpublished dissertation, Katholieke Universiteit Leuven.

Van Hal, Toon. 20I0. Moedertalen en taalmoeders. Het vroegmoderne taalvergelijkende onderzoek in de Lage Landen. Brussel: Koninklijke Vlaamse Academie voor Wetenschappen en Kunsten.

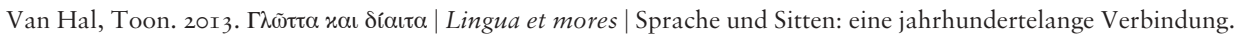
In: Sybille Große, Anja Hennemann, Kathleen Plötner, and Stefanie Wagner, eds. Angewandte Linguistik | Linguistique appliquée. Zwischen Theorien, Konzepten und der Beschreibung sprachlicher Äußerungen|Entre théories, concepts et la description des expressions linguistiques. Frankfurt am Main et al.: Peter Lang, 20I3, pp. $2 \mathrm{I}-3 \mathrm{O}$.

Haßler, Gerda. 20II. Identität durch Sprache. Der Diskurs zur Apologie der Vernakularsprachen bis zum I8. Jahrhundert. In: Cornelia Klettke and Ralf Pröve, eds. Brennpunkte kultureller Begegnungen auf dem Weg zu einem modernen Europa: Identitäten und Alteritäten eines Kontinents. Göttingen: Vandenhoeck \& Ruprecht, pp. $47-69$.

Haßler, Gerda and Neis, Cordula. 2009. Lexikon sprachtheoretischer Grundbegriffe des I7. und I8. Jahrhunderts. Berlin et al.: W. De Gruyter.

Hüllen, Werner. 200I. Characterization and Evaluation of Languages in the Renaissance and in the Early Modern Period. In: Martin Haspelmath et al., eds. Language Typology and Language Universals. Sprachtypologie und sprachliche Universalien. La typologie et les universaux linguistiques. Berlin et al.: W. de Gruyter, pp. 239-49.

Joseph, John E. 20I2. The Genius of the Italian Language: Politics and Poetics. Historiographia Linguistica, 39: 369-77.

Kennell, Stefanie A. H. 2000. Magnus Felix Ennodius: A Gentleman of the Church. Ann Arbor: University of Michigan Press.

De Landtsheer, Jeanine. 2006. Lieveling van de Latijnse taal. Justus Lipsius te Leiden herdacht bij zijn vierhonderdste sterfdag. Leiden: Universiteitsbibliotheek Leiden.

Marti, Heinrich. 1974. Übersetzer der Augustin-Zeit. Interpretation von Selbstzeugnissen (= Studia et testimonia antiqua, I4). München: W. Fink.

Meeus, Hubert. 2006. Twee boecken vande Stantvasticheyt. Een commerciële zet van Plantijn? De Gulden Passer, 84: 79-102.

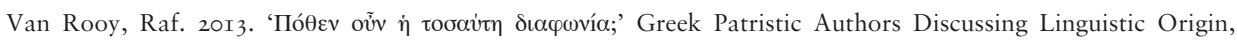
Diversity, Change and Kinship. Beiträge zur Geschichte der Sprachwissenschaft, 23: 21-54.

Schlaps, Christiane. 2000. Das Konzept eines deutschen Sprachgeistes in der Geschichte der Sprachtheorie. In: Andreas Gardt, ed. Nation und Sprache. Berlin et al.: W. de Gruyter, pp. 273-347. 
Schlaps, Christiane. 2004. The 'Genius of Language'. Historiographia Linguistica, 31: 367-88.

Schneiders, Hans-Wolfgang. 1995. Die Ambivalenz des Fremden. Bonn: Romanistischer Verlag.

Siouffi, Gilles. 20I0. Le génie de la langue française: études sur les structures imaginaires de la description linguistique à l'áge classique. Paris: Champion.

Stankiewicz, Edward. I98I. The 'Genius' of Language in Sixteenth-Century Linguistics. In: Hans Geckeler et al., eds. Logos semantikos. Studia linguistica in honorem Eugenio Coseriu I92I-I98I. Berlin and New York: W. de Gruyter — Editorial Gredos, pp. I77-89.

Trabant, Jürgen. 2006. Europäisches Sprachdenken: von Platon bis Wittgenstein. München: C. H. Beck.

\section{Notes on contributor}

As a member of the Center for the Historiography of Linguistics at the University of Leuven, Toon Van Hal has a special interest in the (pre)history of comparative linguistics (in sensu largiori). He mainly focuses on the contribution of Early Modern scholars working in the Low Countries or in Germany and missionaries sent to Central Asia and India.

Correspondence to: Toon Van Hal, Faculteit Letteren, Katholieke Universiteit Leuven, Blijde-Inkomststraat 2I, pb. 3308, 3000 Leuven, Belgium. Email: toon. vanhal@arts.kuleuven.be 